\title{
Conservative Christianity and the Creation of Alternative News: An Analysis of Focus on the Family's Multimedia Empire
}

\author{
Susan B. Ridgely
}

James C. Dobson, founder and CEO of Focus on the Family, is perhaps best known for statements about childrearing. "When a youngster tries this kind of stiff-necked rebellion, you had better take it out of him, and pain is a marvelous purifier," he once wrote, challenging parents to show unruly children "who's in charge." ${ }^{11}$ In books, newsletters, radio broadcasts, and other media, Dobson and other Focus personalities argued that disciplinary pain would ensure that children remembered the appropriate submission to parental authority. This foundational relationship, he claimed, would, in turn, determine the children's future relationships with peers, spouses, bosses, and, most importantly, with God. ${ }^{2}$ Under Dobson's leadership from 1977 through 2009, however, Focus encompassed more than just the advice that parents needed to rear obedient, Christian children. By teaching parents and children the correct way to act at home, through the many books and broadcasts promoted by Focus, the organization influenced how users and their families behaved in schools, at work, and, by the beginning of the twenty-first century, at the voting booth. ${ }^{3}$ Through prescriptive literature for child-rearing, marriage, retirement, and the like, Focus built a platform through which they created a cohesive conservative vision that both built upon and nuanced the wide variety of broadly American and specifically evangelical beliefs in the late twentieth century.

Users of Focus materials, for example, encountered much more than simple suggestions about how to enhance their marriages or get their children to bed with less of a fuss. In the May 1997 newsletter, sent to all the homes who had ordered material from the organization or registered for its mailing list, Dobson described the

Religion and American Culture: A Journal of Interpretation, Vol. 30, Issue 1, pp. 1-25, ISSN: 10521151, electronic ISSN: 1533-8568. (c) 2020 by The Center for the Study of Religion and American Culture. All rights reserved. Please direct all requests for permission to photocopy or reproduce article content through the Cambridge University Press's Reprints and Permissions web page, https://www.cambridge.org/about-us/rights-permissions. DOI: https://doi.org/10.1017/rac.2020.1. 
consequences of women assuming traditionally male roles in the military or, as he termed it, "de-masculanizing" the military. Dobson wrote that the inclusion of female sailors led to "many babies . . . born aboard naval ships in secret," which was bad enough as those births were out of wedlock, but it got worse: "[O]ne suffocated while mom was smuggling it off of the ship." ${ }^{4}$ This example emphasized how the world had turned upside-down with the embrace of women working outside of the home: Women were impregnated by men who were not their husbands while serving in a man's job and were murdering their own children for their career. Focus's "traditional" familial structure, by contrast, sacralized male patriarchal power and white, middle-class family norms at a time when, as the extreme nature of this example demonstrates, Dobson identified them as under an all-out assault. The American story was being reshaped by calling white male power into question. In response, Focus amplified existing conservative Christian beliefs in the nuclear family to draw definitive lines between those Americans who behaved according to God's will and those men and women who refused to submit to Focus's vision of God's divine framework and, thus, threatened both their own salvation and that of the nation.

Rather than taking on the mainstream media directly, Focus used monthly newsletters and magazines replete with Focus-approved mail order products to amplify the message it presented on its AM radio broadcasts. Together these efforts created a conservative Christian clearinghouse with a wide-reaching, self-reinforcing, consciously constructed, closed media community to teach and continually reinforce its message. Through this network, Focus brought then-fringe ideas-such as homeschooling in the mid-1980s and the Christian Reconstructionist notion of true government as one rightfully guided by God-to the mainstream by tweaking existing models accepted within the wider American populous and exploiting lingering suspicions about the current shifts in the home and workplace within the conservative Christian community. ${ }^{5}$ Focus taught that truth was not the story best supported by scientific evidence but, rather, the story that resonated most deeply with one's own "commonsense," which had itself been shaped by Focus's teachings about "traditional" family life. Focus was successful in structuring its version of commonsense Christianity as a bulwark against the sinful world-namely, people and institutions who refused to fulfill their God-ordained roles, especially rebellious children, feminists, and homosexuals, as well as secular "elitists" and government-run social programs that sought to usurp the power of the church. Focus argued that this secular environment tempted Americans to seek out their own desires, such 
as sexual freedoms, divorce, greater acceptance for gender nonconformity, or the like, rather than submit to God's heterosexual, patriarchal design. Through this work, Focus became one of the earliest comprehensive alternative news networks in the United States, helping to create the conditions necessary for the success of later incarnations of alternative media, such as Fox News and Brietbart.

My ethnographic research with Focus users over more than a decade clearly demonstrated how users viewed the organization's teachings and like-minded messages they encountered elsewhere in their lives to be working together to reveal God's truth in the world. While Focus developed the blueprints by which its listeners could build a secure Christian life, individual families were left to interpret those schematics within the structures of their own lives. ${ }^{6}$ Informed by this research, I analyze here how Focus carefully constructed its media empire to ensure that particular aspects of American society would be interpreted as sinful and hazardous for the country's future whereas other policies and practices would be seen as reflective of God's Truth. In so doing, I demonstrate how, by 2016, alternative news sources could use the blueprints that Focus created-such as the Focus-defined traditional family or godly government-to create "pizza gate" and other alternative news stories that read as true to the many Americans influenced by the organization.

\section{Bringing the Evangelical Story Mainstream}

Focus's influence among conservative Christians grew dramatically from the 1990s to the early 2000s, when Dobson's political work as the organization's CEO made him a household name. Born into a long line of Nazarene preachers in 1936, he earned a Ph.D. in child psychology from the University of Southern California in 1967 and then worked at Children's Hospital in Los Angeles and the University of Southern California doing research on children with metabolic disorders. ${ }^{7}$ Three years later, he wrote Dare to Discipline, which provided him with a platform to bring his psychological credentials and interest in ministry together to create a new form of Christian mission anchored in the family. In 1977, he launched Focus on the Family and began short radio broadcasts to dispense information that challenged mainstream parenting and marriage materials, which he felt defied the Bible. A conservative Christian organization, Focus began as a corrective to the women's liberation and the permissive parenting movements. Although it avoided any political labels, it was politically conservative. Rather than create a church or denomination that encouraged corporal 
punishment or sacralized stay-at-home mothers, Dobson created a far-reaching parachurch clearinghouse for materials supporting Christian family life. Through choosing topics for radio broadcasts and Focus-approved books, Dobson acted as a gatekeeper, carefully promoting only his vision of Christianity to his listeners. Although the variety of Focus-approved materials appealed to its growing mailing list, many Americans still did not know about Focus even as they read Dobson's column in one of over 550 newspapers in the United States and Canada, more papers than ran columns by Miss Manners, Dave Barry, or George Will. ${ }^{8}$ In addition, again unaware of his massive organization, Americans listened to Dobson's ninety-second radio spots on more than 230 stations. ${ }^{9}$ With its explicitly Christian half-hour broadcast carried on over four thousand stations by mid-1990s, Focus was the "largest syndicated program in the history of religious radio."10 Moreover, Dobson's mailing list included more than 250 million households-and the organization received so much mail that it warranted its own zip code. ${ }^{11}$ Each person who sent a letter would then automatically begin receiving newsletters and copies of Focus on the Family with James C. Dobson magazine each month. Although Focus was not the first, or only, group to support an interpretation of Christianity as one centered on ensuring that members of the nuclear family fulfill their God-ordained roles as mothers, fathers and children, it became the largest and most easily accessible because of its media empire. ${ }^{12}$

Dobson appeared on the Christian Broadcasting Network (CBN), an effort by televangelist Pat Robertson beginning in 1960 to create an alternative to mainstream media. When Dobson appeared on CBN, he brought his own emphasis on Christian obedience to God through submission to Focus's vision of a traditional family and social structure to a new, perhaps older audience. Simultaneously, these appearances served as just one of many ways that each media outlet promoted the other, creating this self-reinforcing message. Meanwhile, the New York Times and the Washington Post published more than one hundred stories on high-profile CBN and over two hundred stories on televangelists Jim and Tammy Faye Bakker between 1980 and 2004. In that same period, however, they published only seventeen stories on Focus and Dobson. This relative lack of coverage allowed the broader public to remain somewhat unaware of the existence of this thriving media empire and its role as a major shaper of the conservative Christian message, with its promotion of thousands of authors and artists who reflected its views.

To the millions of conservative Christians who were reading and listening to Focus, however, Dobson was the standard-bearer of authoritarian, God-centered childrearing for the average American 
over and against the growing popularity of more (secular) permissive forms of parenting. He emphasized the divine nature of the heterosexual, patriarchal family and the existence of a singular biblically centered, universal truth. Contemporary efforts at gender equality, Dobson argued, pushed Americans away from the godly family described in Ephesians: "Wives submit to your own husbands, as unto the Lord. For the husband is the head of the wife even as Christ is the head of the church. . . Children, obey your parents in the Lord, for this is right" (Eph. 5:22, 6:1-2, ESV). Through this verse, he argued that the Bible outlined that women could come to know God fully only through submitting to their husbands and nurturing their children to know God. Dobson did more, however, than quote this verse. He fleshed out the roles for each family member mentioned, beginning in Dare to Discipline, and nuanced them to address contemporary concerns. The Bible says nothing about women and labor, but working for wages, for instance, became the most significant way wives challenged their husband's authority in Dobson's retelling of the biblical worldview. Women leaving their divine, supporting role in the home, Dobson argued, led to the collapse of American families and, by extension, society. Through his own testimony about the horrors of leaving his daughter at daycare and the stories of countless other men and women who embraced his strategies, he expanded and amplified the arguments of Phyllis Schlafly and other evangelical leaders for audiences that might never have been open to Schlafly's more explicit forms of political messaging. While Free to Be You and Me was airing on network television with the message that mothers could "drive taxis or sing on T.V. Yeah, mommies can be almost anything they want to be," Dobson maintained that only a biblical family-with the father as breadwinner, the mother as homemaker, and children who are obedient-could anchor society. ${ }^{13}$

Focus's approach appealed to those parents who saw nothing to celebrate in these newfound freedoms that seemed to defy moral conventions. In the words of one woman who had been listening to Focus since the early 1990s, Dobson offered "practical advice and encouragement about how to have a Christian principle in your home in today's secular world." For her and many other parents I interviewed, moving away from this version of a Christian family meant sure disaster. She explained, "looking back [at] recent history, when mothers were home and dads started leaving . . . say from the 1950s to now, correlates directly with the family failing. . . . I think it is just phenomenal the relationship, and it blows my mind [that] so many people can't see it." The correlation Dobson made between the Bible, the nuclear family, and a secure society resonated with many 
Americans-so many, in fact, that Dobson originally created Focus on the Family to answer letters from anxious readers.

In the late 1980s and 1990s, as the culture wars were heating up in the United States, Focus stood almost alone as a national media resource for conservative Christian families. Indeed, it was an early media conglomerate. Having saturated the Christian radio airwaves, it began producing a constant stream of video series for Christians of all ages, published multiple magazines, and supported publishing houses that carried fiction and nonfiction imprints as well as licensed material for ministers. To protect Focus's closed-media community, the organization researched each book, group, and interviewee that its productions spotlighted to ensure that each idea reinforced the organization's teachings about current issues in American homes and beyond. ${ }^{14}$ Their mission statement emphasized their goal "to cooperate with the Holy Spirit in disseminating the Gospel of Jesus Christ to as many people as possible, and specifically, to accomplish this objective by helping to preserve traditional values and the institution of the family." ${ }^{15}$ To that end, perhaps, Focus sought to widen its reach by helping to start the men's ministry Promise Keepers and promoting Timothy LaHaye and Jerry B. Jenkins' bestselling Left Behind series, as well as the cartoon Veggie Tales. Moreover, Focus's publishing arm brought thousands of influential conservative Christian texts to market. The organization rejected any programming or publications that challenged its interpretation of the Christian worldview, thus attempting to insulate their listeners from hearing competing voices. Authors, eager to reach the organization's many members, would conform their novels to Focus's brand to help ensure they received the Focus seal of approval.

Even as Focus grew into a multimedia empire, it continued to position itself as a small "David" fighting to preserve divinely ordained gender roles-men as breadwinners and women as nurturers-against the "Goliath" of mainstream media, which promoted the expansion of women's roles and denied the existence of predefined divine roles. Popular sitcoms such as Murphy Brown, Rosanne, Ellen, and Will and Grace normalized the kind of postmodern approach to family that Dobson had long portrayed as sinful. Working against these glitzy Hollywood productions through radio broadcasts was one way Focus could maintain its underdog status with consumers. In contrast to these big-budget productions, Focus sought to appear as a homespun enterprise run by neighbors and friends. Focus's position on the radio dial reinforced this homespun image: In the early years, listeners usually found Focus on the Family Broadcasts on AM stations, sandwiched between Christian talk shows and Bible studies. There were few ads and nothing 
flamboyant. If a listener liked a show and called to ask for a cassette recording of it, her phone call would be answered by a woman much like herself. The operator would record the necessary information, ask for a donation to cover the costs of shipping the tape, and end the call with a prayer. ${ }^{16}$ Similarly, callers with marital or parenting problems would be transferred to a member of the "family resource team" for help. By the 2000s, Dobson's radio broadcasts had expanded to the FM band, and resources could be purchased online, yet a call to Focus would still yield a personal, human interaction. This personal, caring image was embodied by James Dobson himself, who appeared in Focus publications in simple sweaters worn over a collared shirt and donning his trademark oversized glasses that had long since fallen out of fashion. His attire matched his folksy, budget-conscious image, making him look like a congregant posing for a picture in a church directory. Although Dobson put a great deal of effort into portraying himself as an "everyman," a father figure easily accessible to his followers, when advantageous he emphasized his position as a doctor, which granted him assumed authority over his listeners.

Still, "Dr. Dobson," as he was unfailingly referred to by Focus employees and consumers, worked hard to retain his folksy image and keep his organization out of the limelight. Forgoing wider fame for greater practical power allowed Focus's influence to grow in ways that its audience did not perceive. For example, they might hear a sermon at their local church, or a speech at a Republican fundraising event, both of which reinforced what Dobson said on the radio or wrote in one of his books, without realizing that Focus had shaped each communication. One woman that I interviewed stated that she had "been listening to Focus on the Family for a number of years" by the time she became pregnant. She went on to explain that Focus "was so knitted into the fabric of my thinking and beliefs that's it's hard to pick it out now exactly where Focus's influence ends." Focus's multimedia approach allowed Dobson's biblical blueprints to permeate consumers' homes as the broadcasts became constant company while mothers did laundry, tended to their children, acted as the family chauffeur, and washed dishes.

Despite its largescale effort to reform American society, Focus found ways to operate out of view of the mainstream for decades, in part because its overt emphasis on childrearing and families was viewed as apolitical by both those outside the organization and by its users. Its child-centered mission, along with its purposeful overlapping with other conservative evangelical organizations, has also led religious studies scholar Seth Dowland, media studies scholar Heather Hendershot, historian Andrew Hartman, and many 
more academics, regardless of their discipline, to view Focus as the exemplar and, often, the public face of modern-day evangelicalism, particularly in terms of its emphasis on maintaining rigid heterosexual norms and developing a pronatal culture. ${ }^{17}$ While these works contribute tremendously to our broader understanding of evangelicalism in the public sphere, centering individual threads within Focus's teachings obscures the immersive effect of living in a world saturated with Focus-approved media.

\section{Teaching Common Sense}

Focus, like most evangelical organizations, interpreted the Bible using the principles of Common Sense Realism, a nineteenth-century philosophy built on the work of Francis Bacon. In this view of the Bible, the "plainest, most evident reading of the text is the proper one." ${ }^{18}$ While not all Focus users were evangelicals, Dobson promoted the common sense idea that "Truth" with a capital $T$ could be clearly comprehended by those in right relationship with the Lord without special training or fancy degrees. This understanding, Dobson told his listeners, was the common sense, or natural, way to interpret the Bible, and any other interpretation had been influenced by outside forces such as politics.

Scholars such as Clifford Geertz have asserted, however, that the eyes must be trained to see and the ears trained to hear a meaning as common or sensible. ${ }^{19}$ What seems obvious is only obvious to someone who has been reared in a particular way: pancakes make a great breakfast in America-not so in Japan, where they are reserved as a midday treat. Thus, although Focus claimed that there was a universally shared truth evident in the Bible, that was only true if one shared Focus's foundational assumptions. Common sense must, in fact, be taught. This training is the process through which audiences come to their interpretations of reality. ${ }^{20}$

Focus's audience in the early 1980s was primed to receive its message as commonsense "Truth" because that message drew on themes they had already encountered in the mainstream media and in religious circles. These themes included the importance of patriarchy; heterosexual, white, middle-class norms; and mothers who put their families (including both existing children and children they hoped to have) before their own desires. In part, Focus connected with its audience by drawing on a shared nostalgia for an idealized vision of 1950s America. The Christian America that Focus worked toward looked remarkably like the one its listeners had come to know through television reruns of Leave it to Beaver and Father 
Knows Best, where children obeyed their parents, dad was in charge, an apron-clad mom doted on the family, and everything turned out fine in the end.

Although they only existed on a sit-com, the Cleaver family in Leave it to Beaver and the Nelsons from The Adventures of Ozzie and Harriett took on iconic status as the ideal family. Their whiteness and middle-class status were never addressed, their Christianity was assumed, and their family structure was normalized. In the November 1990 issue of Focus on the Family Magazine, readers were reminded of more wholesome and happy times as black-and-white images of these television families were overlaid on a story about the increasing crassness of network television, which was then airing Rosanne, Married with Children, and LA Law. These families from the days before Technicolor, the article instructed readers, were not only iconic; they were also "idyllic." Gary Bauer, former president of Focus's political arm, the Family Research Council (FRC), wrote in his May 1991 article for Focus's flagship magazine:

In the 1950s millions of American families gathered around their television sets to watch the Nelson family do their funny thing. ... They were part of the genre of TV shows featuring intact families, including programs such as "Father Knows Best," "Leave It to Beaver". . . . I doubt if the Nelsons ever thought they would some day [sic] become a symbol for traditional values and lifestyles in the '80s and '90s, but that's exactly what happened. ${ }^{21}$

While Focus authors frequently tied the term "traditional" to biblical values, as in the mission statement quoted above, like Bauer, they also infused this concept with a generalizable nostalgia for the idealized 1950s with all its perceived stability for white, middle class, Christian families. In so doing, traditional for Focus users stretched through 1950s America to the Bible itself.

Through imagery and word choice, Focus grafted its vision of a Christian family (originally inspired by Ephesians) onto American families, especially the Dobsons, using the tropes found in these sitcoms. The Focus audience learned how to see June Cleaver's and Harriet Nelson's steady joy developing from their choice to follow God's will by nurturing their children and meeting their husbands' every need. June fulfilling her role, Focus's consumers could infer, for instance, was what kept Ward, the father, close with his family since it led to them being dependent upon him financially and, therefore, more likely to respect his authority. Dobson, a former varsity athlete who married the homecoming queen, made this 
connection explicit when he spoke of his decision to sell the family car early in his marriage so that his wife could leave her job and stay home with their daughter. This oft-repeated story about Dobson's willingness to sacrifice financially to fulfill God's will for a male breadwinner reminded families to budget more carefully and to remember their divine roles. Like the Cleavers, the Dobsons found happiness because they chose their God-ordained roles as men and women over the temptations of secular society, not because government programs, such as the GI Bill and mortgage interest deductions, helped them to live a comfortable, middle-class, suburban life. Like other retellings at Focus, this reinforced the story of Dobson's life journey as the American story. Focus consumers and leaders often made this connection between the television families of the 1950s and the Christian ideal, as embodied by Dobson, even when their own life experiences in the 1950s and 1960s challenged the notion that these sitcom families represented American traditional norms in those decades. For instance, Jim Daly, Dobson's longtime cohost and eventual successor as president of Focus-who was orphaned, helped raise his siblings, and spent time in foster care -merged this idyllic fictional past onto his own life and his hope for the future: "I grew up in the 60s and you'll hear the Leave It to Beaver analogies and Ward Cleaver and all that, but you know, I can remember that: dads and moms and the roles they played and the stability of the home and coming home and your mom there with warm cookies. That was me growing up. That was kind of traditional America." ${ }^{22}$ Of course, that was not his childhood and not a part of his personal memories, but his understanding of the past had been transformed by the media's, particularly his employer's, depiction of that past in the present.

For Daly, as for many other Americans in the 1950s and earlier, mother was not waiting at the door after school with freshly baked cookies. Historian Elaine Tyler May demonstrates that these postWorld War II idealized families were not "the last gasp of 'traditional' family life with deep roots in the past. Rather, they were the first whole-hearted effort to create a home that would fulfill virtually all its members' personal needs through an energized and expressive life." ${ }^{23}$ This effort came in the wake of historical events that created great stress on family life. By 1928, surveys showed that one in four married men and women admitted to having an affair, and the divorce rate was one in six. ${ }^{24}$ Further, during the Great Depression of the 1930s, in many families, any family member who could earn a living outside the home-mother, father, child-did so. Similarly, during World War II, with young, middle-class white men overseas, many white children in the United States entered daycare 
for the first time so their mothers could go to work to support the war effort. ${ }^{25}$ By the 1950s, the divorce rate had risen to one in five and youth culture had taken root-and with it, concern about juvenile delinquency. ${ }^{26}$ Thirty years later, in stark opposition to the feminist movement of the 1970s, and the empirical reality of the time, the aspirational vision of a family as consisting of obedient children, a doting mother, and a patriarchal father as the norm for American family life had taken hold thanks, in no large part, to the tremendous efforts of Focus.

Part of the effectiveness of this ideal was that Focus allowed it to evolve subtly to reflect change over time while maintaining that it promoted unchanging traditional values. Slowly, broadcast by book by seminar, Focus knit together its ever-growing list of concerns, which eventually included both marriage equality and fear for young boys growing up in a "girl power" world, with its original concerns of discipline, feminism, and family involvement. The result was an all-encompassing vision of how to build and sustain a Christian life-at home, in school, at work, and, finally, in the voting booth. For instance, early Dobson work, such as Dare to Discipline and the Focus on the Family seminars, emphasized that mothers performing their proper roles in the home were essential to creating obedient children in an antiauthoritarian age. In response to a question in Dare to Discipline about why juvenile delinquency was so high, Dobson wrote, "First you have more and more mothers going to work. ... This has deprived children of the constant guidance and sense of security that they need from their mothers at this young age." ${ }^{27}$ By 2005, when the phrase "girl power" was catching on in the wider world and gender-free terms such as "spouse" and "sibling" had become the new norm outside of conservative Christian circles, Focus emphasized the innate and God-ordained differences between men and women. By this time, the Focus narrative had begrudgingly evolved to allow for working mothers, given the economic realities of its many listeners, while using biology to argue against gender fluidity and individual choice.

In advice manuals and broadcasts, Focus argued that these differences-from a girl's supposed love of talking to a boy's supposed testosterone-driven aggression-served to make girls into good nurturers and boys into ideal breadwinners. ${ }^{28}$ "Because of the specialization of their brains" in utero, Dobson argued, "males are typically better than females at math, science, spatial relations, logic and reasoning." He argued that, because of this specialization, men were "designed to provide for their families physically and to protect them from harm and danger." Being a protector and a godly man, as Focus defined it, was not a "lifestyle choice" but an innate feature of 
all people whose $Y$ chromosomes resulted in them being "bathed in testosterone" at birth. By contrast, he argued, "Estrogen is called the 'intimacy hormone' because it stimulates brain circuits that create a desire for bonding, nurturing, and communication. . . . It is what makes her feminine." ${ }^{29}$ According to Dobson, God had designed men and women, boys and girls, for specific tasks. To choose an alternate set of responsibilities was to go against God. Moreover, for the government to encourage such choices by removing stigmas or legal barriers to such choices meant that the nation was no longer a "nation under God," which he argued was the Founding Fathers' original goal for the country. ${ }^{30}$ In its publications and broadcasts, Focus expanded and enriched this basic narrative with references to various sources, including scientific studies and the Bible. This had the effect of portraying these rigid roles for men and women within the family as the commonsense, default positions embedded in the country's traditions rather than as newly manufactured roles created in response to the multiple cultural revolutions of the 1960s and 1970s.

\section{Networking the Closed Media Community}

In many ways, these efforts to develop an alternative news stream mirrors the efforts of those politicos and journalists whom historian Nicole Hemmer calls "First Generation Conservative media activists," who were attempting to change public discourse between 1940 and the late 1970s. These activists developed important platforms for conservative ideas, such as the National Review, to speak out against the hegemony of the mainstream media and to call out its failure to be truly objective. ${ }^{31}$ The efforts of these early media entrepreneurs largely sought to reach a politically oriented audience that was not necessarily guided by religious concerns. Jerry Falwell's Moral Majority and others, including Focus, picked up and expanded these efforts to emphasize conservative Christian concerns beginning in the late $1970 \mathrm{~s} .{ }^{32}$ Focus's ability to blend the ideas of the religious right with seemingly apolitical advice on family life, however, meant that Dobson could reach conservative-leaning Christians who considered political activities un-Christian or simply uninteresting.

Almost from the beginning, Focus reached beyond the American Christian home into national politics as its ties to the Republican Party strengthened throughout the 1980s and 1990s. In 1981, Dobson announced the connection of Focus to the Reagan administration by having Susan Baker, the wife of then-Secretary of the Treasury James Baker, on the Focus board of directors. That same 
year, Dobson founded the Family Research Council, led by Gary Bauer. ${ }^{33}$ Throughout the 1980s, Dobson and Focus continued to try to shape American politics, while Republican lawmakers were influencing Focus's message about how to create a godly family, community, and nation. Although Dobson left no evidence of coordination between the organizations, statements from Focus and those from the Republican National Committee became mutually reinforcing. The connections were often made explicit in Focus's Citizen Magazine, which debuted in 1987 with the mission to keep its "friends informed about political developments threatening the home." ${ }^{34}$ While Dobson was making overt political statements in Citizen Magazine, the mainstream press still assumed that his primary influence came from the work he did on AM radio stations across America doling out practical and, he claimed, "timeless" advice to American mothers. For example, in a New York Times article from 1995 on Dobson's discussions with Republicans, the Times reassured readers that, "Despite such talk, Focus is largely a nonpolitical organization, and it has attracted many people who admire Dr. Dobson's views on marriage, bringing up children and a host of other family issues." ${ }^{15}$ Although Dobson knew that most conservative Christians turned to him for help with their family lives, he would occasionally, without warning, replace a radio broadcast on domestic issues with one on a political issue. ${ }^{36}$ As early as 1983, Focus on the Family with James Dobson, the monthly magazine sent to every family on the mailing list, included a calendar of the radio broadcasts with the note:

Occasionally issues come to our attention that affect the quality of life in the society in which we raise our children and maintain our families. . . But when issues such as pornography, abortion, child abuse, the funding of anti-family organizations by the government, the proposed disarmament of the nation and other social concerns cry out for Christian comment, we will express our views and opinions. ${ }^{37}$

Through these substitutions, Dobson brought his explicitly political message to his wider audience. Although listeners overwhelmingly sought answers to domestic family issues, Dobson increasingly gave them his vision of a biblically centered government. As early as 1990, in the flagship magazine, sent to every family on Focus's mailing list, as well as in Citizen Magazine, the organization highlighted the anti-Christian bias in the mainstream media through articles such as "The Sinking Credibility of the Press." Here, vice president of Focus, 
Rolf Zettersten, emphasized that the mainstream press often joined forces with liberal organizations in their prochoice rallies and in "advocating homosexuality and promiscuity," noting that it is no surprise that "our position is never represented as one supported by mainstream values. . . . After all, Jesus warned his disciples, 'You will be hated by all on account of my name' (Luke 21:17 NASB)." ${ }^{\prime 38}$

Readers of Citizen Magazine had long known that Focus would give them windows into news stories that the mainstream media would not. For example, between 1989 and 1990, Citizen published numerous articles on "The Act for Better Child Care Services" (ABC) that was making its way through Congress; Citizen's description transformed the bill from an effort to support American families, as it was widely described in the mainstream media, into yet another dangerous policy working to undermine them. In March 1989, the New York Times articles focused primarily on how the bill might help two-income families, with articles such as "Child Care: No Shortage of Proposals." In this article, reporter Julie Johnson demonstrated and reinforced Gary Bauer's mainstream status by quoting him alongside Senator Christopher J. Dodd and, President of the Children's Defense Fund, Marianne Wright Edleman. ${ }^{39}$ In July, Citizen Magazine alerted readers to the fact that, "because the child-care benefits would go only to those parents who use the government-licensed facilities, [the bill] discriminated against parents who take care of their own children or choose other forms of substitute care. The bill also would forbid church-based day-care centers receiving federal funds from engaging in "any sectarian purpose or activity." In October 1989, the bill was highlighted through the lens of Focus's idea of proper mothering in the flagship magazine article, "Having It All-At Home: More Than 70 Percent of Married Moms Do Not Work Full Time Year Round." ${ }^{\prime 40}$ A month earlier, Citizen Magazine warned the politically interested reader that "Congress Threatens to Usurp Parents: The Senate's ABC Day-Care Bill Shuns Stay-at-Home Moms, but the House Version Is More Dangerous." The article explained that the bill would "establish a mammoth federal day-care bureaucracy that assists working mothers but does nothing for mothers who forgo outside career to care for their own." It continues, "There is also concern that H.R. 3 will implicitly support abortion. Generally, legislative language prohibiting sex discrimination in federal programs has often been interpreted as requiring pro-abortion policies." ${ }^{\prime 11}$ Abortion was not mentioned in the bill or in any of the mainstream reporting on the bill. Nonetheless, tying abortion to all policies outlawing sex discrimination served to reinforce the perils of women in the workplace. 
On this policy and others, Focus used its multiple media platforms to create an image of the world in which its Christian views about women's roles in the home were in the majority even as they were being actively marginalized in Washington, D.C., and on television shows such as Murphy Brown and Roseanne. Moreover, Focus began to design an overarching blueprint for a godly life (and, by extension, a godly society) using both its widely available media offerings-radio broadcasts and Focus on the Family with James C. Dobson magazine-alongside more targeted products such as Citizen Magazine and Focus on the Family Physicians, which analyzed these broad topics in politics, health care, or other areas of specialization with the intent to contextualize the policies within Focus's ideal Christian worldview. Therefore, although some readers might only have seen the article on the popularity of "stay-at-home mothering," other Focus users would have also read the Citizen Magazine article or listened to a Focus broadcast that would have reinforced the more potent threat of marginalizing non-wage-earning mothers while valorizing their wage-earning counterparts-a threat that highlighted that, although the mainstream press celebrated efforts to end sex discrimination, in fact, these efforts blurred the fundamental, biblical lines between men and women. When taken to its extreme, as in Dobson's account of the consequences of allowing the "demasculinzing" of the military, this blurring, according to Focus, leads to women turning away from motherhood and toward abortion. ${ }^{42}$

Seven years later, many Focus users had gotten the message about mainstream media and began to turn to Focus to supplement the nightly news and their local papers. In 1997, Focus surveyed their listeners about this shift in emphasis and claimed that, of the 160,000 respondents, over 95 percent said something like "'We find it very valuable to learn what we're not hearing elsewhere in the media. Please continue this service and thank you for defending what we believe to be true.' An additional 4\% said, 'Yes, continue to keep us informed, but please do it less often.'"43 Even if these numbers generated in-house are inaccurate, they represent Focus's desire, as far back as the Clinton administration, to create a world in which conservative Christians were augmenting, if not replacing, their consumption of mainstream media with stories that were crafted to highlight how a particular form of Christianity offered stability in an otherwise ever-changing and dangerous world. By 2000, Dobson's listeners who had questions could turn to the internet for answers. Such a search would often begin with the Focus on the Family website; in turn, it linked to numerous other Focus-sponsored sites on parenting, prolife efforts, homosexuality, 
conservative politics, and other issues the organization considered to be centered on "family." In this way, simple searches could turn into political lessons, often without Focus's name attached. In fact, one need not be searching for Focus on the Family material to be directed to Focus-sponsored sites. From the various URLs and homepages, it appeared as if some sites had been independently produced, even though they were all Focus products. Through its website, Focus extended its closed media community, seeking influence far beyond America's nurseries and playrooms to politics and the floors of the House and Senate in Washington.

Religious studies scholar Ludgar H. Viefhues-Bailey describes Focus's web presence as a web itself:

The internet presence of Focus demonstrates well that this is an organization embedded in and spinning a wide web of references and discourses. More inspirational sites (such as Dobson's Family Guide) are linked to other websites presenting allegedly scientific information about homosexuality, and from there we can click on pages about how to make schools safe for Christian children and connect to Citizenlink, Focus's explicitly political information site. ${ }^{44}$

Focus combined its online presence with its radio programs, magazines, monthly newsletters, and children's radio theater to cross-reference and reinforce its message. The overlapping media stories from a variety of contributors and linked organizations, all with the same basic outlook and conclusion, created the illusion of widespread consensus and agreement with Dobson, a conclusion that Dobson bolstered by reusing testimonies and study data throughout his career to further affirm the unchanging nature of his traditional teachings.

As Focus was promoting its eternal, commonsense model of the Christian family for its typical audience members, Dobson was also targeting another, more elite, audience-the leadership of the Republican Party. This work, however, was rarely publicly acknowledged. In 2004, for instance, a New York Times headline read, "Warily, a Religious Leader Lifts His Voice in Politics" for a story on Dobson's efforts to support antimarriage-equality candidates. A year later, Dobson made the nightly news with statements to the Family Research Council, which officially separated from Focus in 1992, regarding the "We Are Family" video for children, which presented many types of families including those with two mothers or two fathers. Here, he questioned the alleged gender-bending influence of 
the cartoon character SpongeBob, who was depicted in the video holding hands with his friend, Patrick, a pink starfish. ${ }^{45}$ Finally, he made his first ever endorsement of a presidential candidate: John McCain. Soon after that endorsement, Dobson left the Focus organization he had built at least in part so that he could be more overtly politically active. Whatever his ambitions may be or have been in the public sphere, his role shaping millions of Americans' understanding of his version of Christian common sense-which would influence their decision making in their homes, their schools, their workplaces, and their polling places-may prove to be his lasting legacy.

\section{Discerning Truth through Design}

Although Dobson's political messages might have occasionally reached the mainstream, few outsiders noticed that Focus was creating its self-reinforcing networks to influence matters far beyond the home by training its followers to employ the home's godly blueprint in judging a wide variety of social issues. Although this scheme had long been present in Focus materials, it was not until the 2006 video series, The Truth Project, that the organization made it explicit. As Dobson was planning to leave the organization, he seemed to want to ensure that Focus audiences would continue to see the broader world according to his understanding of right and wrong, sinful and righteous, and, perhaps most significantly, threatening and safe. As the host of this video series, Del Tackett-a graying, white, Bill Moyers-esque figure-explained, the "Truth" is revealed in all spheres of life through "God's triune stamp." God, he said, presented himself to the people in the New Testament in three equally important persons - the Father, the Son, and the Holy Spiritall of whom had specific and clearly defined roles: God, the father, is the authority; Jesus is the son who submits himself to God; and the Holy Spirit manifests God's grace. The Truth Project informed its viewers that a Christian family bore the triune design of God, with the Father at the head; the mother as the helpmeet; and the children, the product of that union, obedient to their parents. ${ }^{46}$

This triune design, this stamp of godly approval, viewers of The Truth Project were taught, extended far beyond the home. Each week The Truth Project addressed a different sphere of life. It demonstrated how society in the United States could function if it did not stifle-through the government, the rise of feminism, and "political correctness"-Christian discourses and, in so doing, remove God's influence from key relationships, especially in the 
family, the government, and the workplace. According to Focus, godly policies about labor, for instance, must focus on the trinity of the owner (the steward of God's creation), the worker, and the goods produced. Unions, the government, or other intermediaries broke the bonds of this triune relationship, which angered God and invited instability. The efforts of these intermediaries to care for the sick and needy through benefits packages and entitlements were framed as more than simply un-Christian acts; they were government-sanctioned theft and covetousness. For instance, a truly godly leader, Tackett argued, would "end the inheritance tax, since 1 King 21 states, "The lord forbid that I give you the inheritance of my father.'" Excessive taxation and governmental efforts to create social safety nets took away the opportunity for the Christian wealthy and their institutions to fulfill their responsibilities to those in need by leaving them "gleanings" to harvest. Tackett argued that God wanted those without jobs to have the "privilege to work with their hands. . . Not to give them a handout and destroy them." ${ }^{47}$ Within Focus's biblical blueprint, the current secular American government was continually positioned as commandeering Christianity's role, keeping people, their families, and churches from being fulfilled. By contrast, in Focus's ideal government, "Governors and magistrates hold their power purely as delegates and representatives of the King of all kings. They are appointed and armed with the sword in order that they might 1) punish evil and 2) condone good." ${ }^{\prime 8}$ Here the government exits solely to maintain order so that the church and the family can fulfill their divine roles by offering support to the needy, comfort to the sick, and education for the children. To this end, the $\mathrm{ABC}$ bill did not offer a bit of relief for working families but, rather, represented government overreach, "usurping" the God-given role of parents to care for their children. When the government moves beyond its role of maintaining law and order, Tackitt taught that Christians should resist, as they did with the passage of the Affordable Care Act. When government is fulfilling its divine and limited mission, however, people and agencies who ignore or resist its laws and regulations are opposing God's will and pose a threat to social order, be they feminists, LGBTQ+ activists, or children. For instance, when Attorney General Sessions defended the Trump administration's "zero tolerance" border policy by arguing that separating children from their parents was a biblical gesture, citing "the Apostle Paul and his clear and wise command in Romans 13 to obey the laws of the government because God has ordained the government for his purposes," many in the mainstream media were aghast. Americans influenced by Focus, however, were likely to have agreed with him. After all, this verse was used in The Truth Project 
and elsewhere to define the triune stamp of God in limiting government and in labeling those who obey a godly government as good and those who disobey as needing to be punished, be they parents or children.

Using this template, Focus's consumers could easily determine if seemingly secular issues-from workplace dynamics to border policies-were being discussed rightly by focusing on whether members of the community were fulfilling their prescribed roles within the divine triune design. If persons and the law were aligned with the design, they were presumed to be godly; if they challenged this design, they were presumed to be wicked and dangerous. It is no surprise, then, that conservative Christians view today's world as full of hazards, leading them to believe fake news, particularly negative fake news stories, more often than liberals. ${ }^{49}$ After all, they can see that many Americans all around them are blatantly rebelling against conduct and action these Christian believe to be mandated by God in favor of sectarian solutions to social ills. Likewise, they often view universities as misguided by putting evidence-derived science at the core of their teachings even when it deviates from biblically based truth.

Alternative news outlets and fake news bots can then use this religious template that Focus developed through its own closed media system to help ensure that they appeal to viewers by articulating stories that affirm the truth of the triune design. Focus members, for example would not have been surprised that Bill Clinton had affairs; after all, Hillary Clinton violated her triune role by being a working mother who literally wore the pants in her family. Extending belief in this breakdown of Hilary's own family through her refusal to submit to God's role to the widely circulated fake news story that the Clintons were running a child pornography ring out of a pizzeria in Washington, D.C., ("Pizzagate") is not a far leap given that she had, in their view, forsaken her role as the nurturer and protector of children. As such, a belief in the authenticity of "Pizzagate" exemplifies, for many conservative Christians, people who chose to defy God and refused to fulfill their biblical roles and, thus, were presumed to be capable of any evil. To recognize that evil is to affirm one's own standing on the side of Truth.

The root of this Truth reaches back to the image of the family in which men (particularly heterosexual, white men) have authority on earth as God did in heaven. By the 2000s, that underpinning had come unmoored with more and more women, people of color, and LGBTQ+ individuals taking leadership roles in society. Whereas Focus reinforced this notion of heterosexual, white, male authority with folksy Dr. Dobson on the radio (and in 2008 with Tackett in the 
tweed jacket and khaki pants as the consummate professor in The Truth Project), the network news was taking a different tack to connect to its increasingly diverse audience by introducing new voices into the anchor chair. Across mainstream media, white men, such as Walter Cronkite, used to tell America "the way it is" each night: Cronkite (CBS 1962-1981) and then Tom Brokaw (NBC, 1982-2004), Peter Jennings (ABC, 1983-2005), and Dan Rather (CBS 1981-2005). All of these newsmen began their careers and built trust with their viewers as evening news anchors before the culture wars and "fake news" allegations fully blossomed. Although viewership had been declining since they took their posts, these men held their own against CNN and the newest competitor, Fox News. By 2008, however, more Americans watched cable news than the three major networks combined, with Fox News receiving the most viewers. Although many issues contributed to this shift to cable news, one mostly overlooked factor is that the anchors who took over these coveted network news anchor chairs did not fit Focus's triune design. By the mid-2000s, many of these trusted white male anchors had been replaced by women, as well as men of color, first by trailblazers such as Barbara Walters followed by anchors and journalists such as Katie Couric, Kate Snow, Ann Curry, Elizabeth Vargas, Andrea Mitchell, and Diane Sawyer. From Focus's perspective, the rise of these female anchors and reporters represented people out of place, violating the triune stamp. They were women out of the home usurping male authority; on occasion they were minorities like Lester Holt or Don Lemon who, Focus users might suspect, were likely to advocate for a multicultural agenda rather than God's singular Truth.

Many conservative Christians believed that the mainstream news as voiced by these contemporary journalists and anchors undermined godly design with their efforts to be ever more inclusive in their on-air personalities and their storytelling. Alternative news sources now accessible on cable television filled the vacuum by promoting stories that resonated with Focus's particular version of white Christian "common sense." For example, on Fox News Channel, women and minority hosts, such as Laura Ingraham and Juan Williams, could use their representative diversity to justify the claim that the particular interpretations espoused on the channel were not those of the embattled white Christian patriarchy but, rather, the singular universal truth. In this way, these hosts played the helpmeet role to the authoritative white male hosts such as Sean Hannity, Bill O'Reilly, and Lou Dobbs, many of whom had grown their own audiences through AM radio. They could use the fact that conservative Christians viewed them as speaking from a Godly 
position to expand and enliven Focus's closed-media community into today's contemporary echo chamber.

Susan B. Ridgely is Professor of Religious Studies at the University of Wisconsin-Madison.

\section{Notes}

I would like to thank Ann Burlein, Julie Byrne, and the students at Hofstra University who gave me feedback on an early draft of this article.

Dobson, Dare to Discipline (Wheaton: IL: Tyndale House, 1970), 16, 14.

'Dobson, Dare to Discipline, 14

${ }^{3}$ For more on the interconnections between religion and parenting practices in the United States and the ways in which childrearing manuals are efforts at shaping adults, see Kathryn Lofton, "Religion and Authority in American Parenting," Journal of the American Academy of Religion 84, no. 3 (September 2016): 806-41.

"James C. Dobson, "De-Masculinizing the Military," Focus on the Family Newsletter, May 1997, 4.

${ }^{5}$ For more on Christian Reconstructionism, see Julie J. Ingersoll, Building God's Kingdom: Inside the World of Christian Reconstructionism (New York: Oxford University Press, 2015).

${ }^{6}$ All interviews were conducted in confidentiality, and the names of interviewees are withheld by mutual agreement; recordings and transcripts are held by the author. For more on my methodology see, Susan B. Ridgely, Practicing what the Doctor Preached: At Home with Focus on the Family (New York: Oxford University Press, 2016), 13-19.

${ }^{7}$ Rolf Zettersten, Dr. Dobson: Turning Hearts toward Home (Colorado Springs, CO: Focus on the Family Press, 1989), 85.

${ }^{8}$ "Look Out, Dear Abby! Dobson Column Carried by over 550 Papers," Church and State, September 1999, 19.

"Wendy Murray Zoba, "Daring to Discipline America," Christianity Today Vol. 43 Issue 3, 32.

${ }^{10}$ Sean Connable, "The 'Christian Nation' Thesis and the Evangelical Echo Chamber," in The Electronic Church in the Digital Age: Cultural Impacts of Evangelical Mass Media, ed. Mark Ward and Daniel A. Stout (Santa Barbara, CA: Paeger, 2016), 191.

${ }^{11}$ Dan Gilgoff, The Jesus Machine: How James Dobson, Focus on the Family, and Evangelical America Are Winning the Culture Wars (New York: St. Martin's Griffin, 2008), 39, 168. 
${ }^{12}$ Robert Waterman McChesney, The Political Economy of Media: Enduring Issues, Emerging Dilemmas (New York: Monthly Review Press, 2008), 428-30.

${ }^{13}$ Marlo Thomas, Marlo Thomas and Friends, Free to Be . . Y You and Me (New York: Arista, 1972).

${ }_{15}^{14}$ Gilgoff, The Jesus Machine, 65-66.

${ }^{15}$ "Focus on the Family: Our Faith, Values, Mission and Guiding Principles, n.d., received with the November 1995 newsletter, 5. Although Focus hoped to "bring the message to those in the secular marketplace who may not be familiar with Christian principles," from 2009 forward it primarily supported white families in creating and maintaining a Christian environment in what they saw as an increasingly secular world. In 1990, Focus's members were primarily mothers between the ages of twenty-five and forty with some higher education; today, they are somewhat older but no more diverse. See Laura Sessions Stepp, "The Empire Built on Family and Faith: Psychologist James Dobson, Bringing his Evangelical Focus to Politics," Washington Post, August 8, 1990, C1. Contrary to Dobson's ideal, many of these women worked outside the home to maintain their mostly middle-class status. See Ann Burlein, Lift High the Cross: Where White Supremacy and the Christian Right Converge (Durham, NC: Duke University Press, 2002), 122.

${ }^{16}$ Author's phone call to Focus on the Family Paloma, California, April 1996.

${ }^{17}$ See, for example, Seth Dowland, Family Values and the Rise of the Christian Right (Philadelphia: University of Pennsylvania Press, 2015); Andrew Hartman, A War for the Soul of America: A History of the Culture Wars (Chicago: University of Chicago Press, 2015); Heather Hendershot, What's Fair on the Air? Cold War Right-Wing Broadcasting and the Public Interest (Chicago: University of Chicago Press, 2011); Kevin M. Kruse, One Nation under God: How Corporate America Invented Christian America (New York: Basic Books, 2015); and Natalia Mehlman Petrzela, Classroom Wars: Language, Sex, and the Making of Modern Political Culture (New York: Oxford University Press, 2015).

${ }^{18}$ Randall Balmer, Mine Eyes Have Seen the Glory: A Journey into the Evangelical Subculture in America, 4th ed. (New York: Oxford University Press, 2006), 24. For more on the history of Scottish Common Sense Realism, see George Marsden Fundamentalism and American Culture (New York: Oxford University Press, 2006), 55-56.

${ }^{19}$ Clifford Geertz, Local Knowledge: Further Essays in Interpretive Anthropology (New York: Basic Books, 2000), 84.

${ }^{20}$ For the original argument for cultivation theory, see George Gerbner and Larry Gross, "Living with Television: The Violence 
Profile," Journal of Communication 26, no. 2 (June 1976): 172-99. For more contemporary uses that extend cultivation theory beyond views of violence, see L. J. Shrum, "Television and Persuasion: Effects of the Programs between the Ads," Psychology and Marketing 16, no. 2, (March 1999): 119-40; L. J. Shrum, James E. Burroughs, and Aric Rindfleisch, "Television's Cultivation of Material Values," Journal of Consumer Research 32, no. 3 (December 2005): 473-79.

${ }^{21}$ "Focus on the Family: Our Faith, Values, Mission and Guiding Principles, n.d., 5.

${ }^{22}$ Gilgoff, The Jesus Machine, 54. For more on Focus president Jim Daly's biography, see: https://www.focusonthefamily.com/ about/media/jim-daly/.

${ }^{23}$ Elaine Taylor May, Homeward Bound: American Families of the Cold War Era, 20th Anniversary Edition (New York: Basic Books, 2008), 13.

${ }^{24}$ Cited in Stephanie Coontz, Marriage, a History: How Love Conquered Marriage (New York: Viking Press, 2005), 202.

${ }^{25}$ For a history of the myths of the American family, see Stephanie Coontz, The Way We Never Were (New York: Basic Books, 1993).

${ }^{26}$ Nathan Miller, New World Coming: The 1920s and the Making of Modern America (New York: Simon and Schuster, 2003), 271; Sarah Pike, "Youth Rites: Religion and the Cultural Construction of Adolescence," in Children and Religion: A Methods Handbook, ed. Susan B. Ridgely (New York: New York University Press, 2011), 34-35.

${ }^{27}$ Dobson, Dare to Discipline, 83.

${ }^{28}$ James Dobson, Bringing up Boys: Practical Advice and Encouragement for Those Shaping the Next Generation of Men (Wheaton, IL: Tyndale House, 2001), 19-21.

${ }^{29}$ James Dobson, Bringing up Girls: Practical Advice and Encouragement for Those Shaping the Next Generation of Women (Wheaton, IL: Tyndale House, 2010), 29.

${ }^{30}$ See, for example, "Lesson 10-The American Experiment: Stepping Stones," in The Truth Project Lesson Guide (Colorado Springs, CO: Focus on the Family, 2006).

${ }^{31}$ Nicole Hemmer, Messengers of the Right: Conservative Media and the Transformation of American Politics (Philadelphia: University of Pennsylvania Press, 2019), 101-107.

${ }^{32}$ Hemmer, Messengers of the Right, 252-56.

${ }^{33}$ Linda Kintz, Between Jesus and the Market (Durham, NC: Duke University Press, 1997), 113. Within these political organizations, Dobson came into contact with Pat Robertson, Ralph Reed, Phyllis Schlafly, Bill Bright, and other leading conservatives. The list of guests on Focus on the Family broadcasts made these connections overt, while the similarities between Dobson and the other members 
may signal the success of efforts to present America with a more coherent conservative Christian message, such as the Council for National Policy (CNP). For more, see Edward Ericson Jr., "Behind Closed Doors at the CNP," Church and State, Vol. 49 Issue 6 (June 1996), 4 .

${ }^{34}$ "Resources for the Home: The Citizen Magazine," Focus on the Family Magazine, January 1987, 4.

${ }^{35}$ Gustav Niebuhr, "Advice for Parents, and for Politicians," New York Times, May 30, 1995, A-12.

${ }^{36}$ Niebuhr, "Advice for Parents." Niebuhr's article describes a 1992 random survey telephoning 1,204 people on its mailing list, which found that the Focus audience (primarily educated women, ages 30-49, married with two or more children) were primarily interested in marital issues (91\%), followed by parenting issues $(85 \%)$, and then abortion.

${ }^{37}$ "Coming Broadcasts," Focus on the Family with James Dobson, November 1983, 14.

${ }^{38}$ Rolf Zettersten, "The Sinking Credibility of the Press," Focus on the Family with James Dobson, January 1990, 23.

${ }^{39}$ Julie Johnson, "Child Care: No Shortage of Proposals" New York Times, March 26, 1989.

${ }^{40}$ Beth Spring, "Having It All—At Home: More than 70 Percent of Married Moms Do Not Work Full Time Year Round," Focus on the Family, October 1989, 5-7.

${ }^{41}$ Beth Spring, "Having It All-At Home: More than 70 Percent of Married Moms Do Not Work Full Time Year Round," Focus on the Family, October 1989, 5-7; David Wagner, "Congress Threatens to Usurp Parents: The Senate's ABC Day-care Bill Shuns Stay-at-Home Moms, but the House Version Is More Dangerous," Focus on the Family Citizen, September 1989, 13.

${ }^{42}$ Dobson, "De-Masculinizing the Military," 4.

${ }^{43}$ James C. Dobson, "Responses to Focus on the Family Public Policy Aspect," Focus on the Family Newsletter, May 1997, 1.

${ }^{44}$ Ludger H. Viefheus-Bailey, Between a Man and a Woman? Why Conservatives Oppose Same-Sex Marriage (New York: Columbia University Press, 2010), 8.

${ }^{45}$ John A. Lawrence, "Cartoon Character . . . or Political Animal?" New York Times, January 25, 2005, A-18.

${ }^{46}$ Dell Tackett, "Lesson 7: Sociology: The Divine Imprint," in The Truth Project Video Series (Colorado Springs, CO: Focus on the Family, 2006).

${ }^{47}$ "The Truth Project Tour 11-Labor: Created to Create," in The Truth Project Video Series (Focus on the Family, 2006). 
${ }^{48}$ "The Truth Project Tour 9-The State: Whose State?" in The Truth Project Video Series (Focus on the Family, 2006).

${ }^{49}$ Olga Khazan, "Why Fake News Targeted Trump Supporters," Atlantic, February 2, 2017, accessed December 5, 2017, https://www.theatlantic.com/science/archive/2017/02/why-fakenews-targeted-trump-supporters/515433/. For more on how liberals and conservatives view the media, see Amy Mitchell, Jeffrey Gottfried, Jocelyn Kiley, and Katerina Eva Matsa, "Politics, Polarization and Media Habits," accessed April 14, 2018, http:// www.journalism.org/2014/10/21/political-polarization-media-habits/

ABSTRACT In this article, I explore how, from 1977 through 2009, the conservative Christian media empire, Focus on the Family, acted as a model for and a creator of alternative news long before the 2016 election. In particular, since 1977, Focus linked proper Christianity with recognition of a world of hazards by defining danger as those people and institutions who refused to submit to God, especially feminists, secular universities, and the welfare state. Through the creation of a closed-media network, Focus taught Christian conservatives to see the mainstream news as undermining biblical Truth by espousing stories that supported postmodern relativism over God's singular truth. Simultaneously, Focus generated its own news sources to fill the vacuum left by the mainstream with stories highlighting the political and social structures needed to support the Focus-defined traditional family. Soon, other conservative media outlets began using these frameworks to attract listeners and to add veracity to their stories. Although mainstream media portrayed Focus as passé by 2009, I argue that the model that Focus developed led seamlessly to the creation of Fox News and, later, to the formation of internet communities around outlets such as Breitbart and to the believability of Russian bots. 